\title{
INGREDIENTS OF QUALITY EDUCATION AT TERTIARY LEVEL: AN ASSESSMENT OF HIGHER EDUCATION IN BANGLADESH
}

\author{
Mohammad Nur Ullah \\ Lecturer, Department of Public Administration, Bangladesh University of Professionals (BUP), Mirpur \\ Cantonment, Dhaka-1216, Bangladesh
}

\begin{abstract}
The fundamental philosophy of a country's socio-economic, political, and cultural development is ensuring quality education from primary to tertiary level. Quality Education refers student centric learning system which helps to achieve objectives and outcomes of a specific program and ensures that students really learn to meet the needs and demands of the market, the society and the nation as a whole. It is found that there are some important ingredients affecting quality education of a state such as socio-economic condition, curriculum and syllabus, faculty recruitment system, faculties and their skills and expertise, secured environment, application of diverse teaching instructions, setting learning outcomes and objectives, students and their engagement etc. However, Bangladesh higher education is still struggling in ensuring quality education due to having several challenges like Politics in faculty recruitment, weak assessment and monitoring system, lack of accountability of faculties and administrative staffs, unexpected politics in educational institution, weak curriculum and syllabus, lack of quality research, limited infrastructural facilities, missing of modern teaching aids etc. Therefore, this study is an attempt to diagnose the current state of Bangladesh higher education in order to finding the problems out and presenting policy note to ensure quality education at tertiary level of Bangladesh.
\end{abstract}

Keywords - Education, Quality Education (QE), Tertiary Education (TE), Active Learning (AL), Learning Outcome (LO)

\section{INTRODUCTION}

A nation cannot be developed unless considering the essence of quality education at the top. The importance of quality education is massive on socio economic development of a country; because of that napoleon said, "Give me an educated mother; I will give you an educated nation". Having quality graduates is a blessing for a country which might be a way forward to be the best. However, Bangladesh got its independence since 1971 by a blood bleeding war and dreaming of being developed economy of the world. In this regard, nothing is there rather ensuring quality at all levels of education. Giving concern to the quality education at tertiary level has been increasing since last couple of years in both public and private universities of Bangladesh (Islam and Himel, 2018). But Rashid and Rahman (2017) states increasing the number of universities, students, faculties, will not be enough if you do not bother the system that ensures standard education. The scenario of tertiary education is not standard as compare to developed countries because of geographical realities, corruption and narrow game of politics, weak control of UGC over top of the public and private universities (Hossain, 2017) and shortage of faculties in private universities, not having global rankings, faculties involvement to other professions, no existence of research university rather teaching (Hassan, 2017). It severely affects the quality of Higher education in Bangladesh. Bernard (1999) and Adams (1993) pointed that the quality in education encompasses some significant ingredients like potential students, safe and secured educational institutions, skilled faculties, good relation between teachers and students, outcome-based education, teaching instructions etc. Thus, Bangladesh must work with quality education which will be the right weapon for achieving the landmark of vision 2041.

\section{OBJeCtive OF THE STUdY}

This paper has a fundamental objective is to analyze the facts and figures of quality education system with a view to realizing the quality of Bangladesh higher education. This paper has some specific objectives are following;

- To examine the major and effective ingredients of 'Quality Education' at tertiary level.

- To diagnose the hindrances of quality higher education system in Bangladesh.

- To propose a possible guideline for ensuring quality in higher education of Bangladesh.

\section{SignificANCE OF THE STUDY}

In the era of globalization and competition, quality education is considered as only tool for prosperity and development. Quality graduates are the most important resource for uplifting country's flag in globalized economy (Rahman, 2010). Wherever, the position of Bangladesh regarding quality higher education is very cheaper than the other developed nation and 


\section{International Journal of Engineering Applied Sciences and Technology, 2020 \\ Vol. 4, Issue 11, ISSN No. 2455-2143, Pages 546-556 \\ Published Online March 2020 in IJEAST (http://www.ijeast.com)}

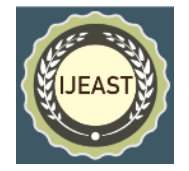

it is becoming alarming day by day (Salahuddin and Aminuzzaman, 2011). Andaleeb (2019) stated that students are more concerned with memorizing rather knowing the connection of content to reality. On the contrary, teachers are focusing on lecturing rather applying many other teaching instructions. Other stakeholders are reluctant to ensuring quality because of corruption and politics. So, it is essential and worthy to evaluate real facts behind the broken scenario of Bangladesh higher education system where developed societies are considering quality higher education as fundamental element of mainstream development. I would like to point it out that the following reasons make the study time worthy and meaningful;

- This study will provide comprehensive knowledge of quality education and its ingredient through describing different world best literatures and accumulating it into this paper.

- It will contribute to the world literature regarding knowing quality education system of Bangladesh. The reader will be well off more from this study with detailed discussion of real scenario.

- $\quad$ This paper will help the policy maker to take the right policy of quality higher education by identifying gaps or problems of existing system.

- Further researcher may get a solid direction of doing his research in this specific area if anyone wants to do.

- Society will be benefited with national development if the proposed suggestions will be taken by the respected authority.

\section{LITERATURE REVIEW}

Hossain (2017) examines some important factors that affect the quality of higher education in Bangladesh. The factors have been identified in this paper are student intake, faculty recruitment, staff development, teaching method library and laboratory. The paper also mentioned some external factors like, politicization, unplanned expansion, financial constraint, corruption. Some challenges have been analyzed in this writing that Bangladeshi universities are facing. He said that the government of Bangladesh has already taken some initiatives to recover the challenges and improve the quality in tertiary education. Among the initiatives, Higher Education Quality Enhancement Project (HEQEP) is the important one. The paper mainly deals with HEQEP project; how does the project work to improve the quality of higher education in Bangladesh.

Akter (2017) shows the facilities are being provided by renowned private universities in Bangladesh and abroad. Furthermore, some differences between the facilities of public and non-government universities are highlighted. Research and expert opinion seems to indicate that the quality of education of many of these universities is below par; many of them depend on part-time, inexperienced faculty. On the other hand, different facilities like, laboratory, library facilities etc. are not satisfactory. Many of the students were not familiar with the online education system such as courses being uploaded on the internet, attending class from home through servers, online library facilities, etc.

Sarker et al, (2013) addresses some challenges of quality education in public universities of Bangladesh. The challenges mentioned in this study are lack of modern teaching aids, library facilities, availability of necessary books and journals, research facilities and laboratory facilities. The paper discovered the relationship between budgetary provision and quality of higher education and evaluated the teachinglearning system in public universities of Bangladesh.

Mohsin and Kamal (2012) conducted a comparative study among Singapore, Malaysia, and Bangladesh regarding managing quality higher education. The paper states that the higher education sector of Bangladesh, both public and private, is regulated by the Ministry of Education, there is no legal body in Bangladesh except University Grant Commission to ensure the quality of higher education. In addition to this, this study has also found that there is no accreditation agencies, no accountability system and no academic auditing system in Bangladesh to ensure the quality of higher education though these three key important factors has already been ensured both in Singaporean and Malaysian system of higher of education. It is also observed that a bundle of supportive strategies have been active in those countriesSingapore and Malaysia. Finally, the researchers have put some way forward for Bangladesh to be followed to develop the nascent condition of quality in higher education institutions.

U.S. Department of Education (2006) has pointed out the ingredients of quality higher education where a program must contain the following qualities: institution's mission, Curricula, Faculty, Facilities, equipment, and supplies, Fiscal and administrative capacity as appropriate to the specified scale of operations, Student support services, Recruiting and admissions practices, academic calendars, catalogs, publications, grading, and advertising, Measures of program length and the objectives of the degrees or credentials offered, and Record of student complaints received by, or available to, the agency

Andaleeb (2003) in his study focused nine critical factors to revitalize quality of higher education. These factors are; teacher quality, method and content, peer quality, direct facilities, indirect facilities, administrative efficacy, political climate, gender effects and expected satisfaction with higher education. In his research, he revealed these areas seem to need greatest attention. In every area he pointed out some indicators or issues to explore the reality. 


\section{International Journal of Engineering Applied Sciences and Technology, 2020 \\ Vol. 4, Issue 11, ISSN No. 2455-2143, Pages 546-556 \\ Published Online March 2020 in IJEAST (http://www.ijeast.com)}

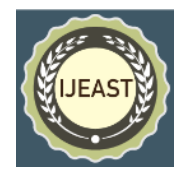

Above mentioned literatures give a narrow analysis of factors affecting quality higher education and challenges of quality education in Bangladesh higher education system but they didn't give any explicit framework that can improve the quality of higher education in Bangladesh. This paper addresses the core factors that directly connected to the quality education and find the gap of Bangladesh higher education system. And the later part, paper tried to draw a framework which will help the authority and policy maker to take the better decision in ensuring quality of higher education in Bangladesh.

\section{Research Design AND Methodology}

Qualitative analysis of social research has been taken for this study. It is also descriptive with secondary sources of data from different research articles, journals, newspaper-based information and online resources. For this study purpose, the education policy of 2010 and 37th annual report of UGC in 2018 have also been analyzed. This study also followed the content analysis method of research. A comprehensive literature review has been done for this study and tried to understand the research gap. This research has been conducted on this gap that identified by the literature review.

\section{QUALITY IN EDUCATION}

Quality education is the standard of education helps to meet the demand of the society, market and the state. A paper presented by UNICEF at the meeting of The International Working Group on Education Florence, Italy June 2000 titled "Defining Quality in Education" identified five components of Quality Education such as quality learners, quality environment, quality content, quality process and quality outcome. A quality learner includes good physical condition and nutrition, physically and psychologically fit students learn more than the others (McCain \& Mustard, 1999), regular attendance, family supports. Quality learning environments indicates the physical facilities of the institutions, psychological elements like security, safety (Sutton, 1999), teacher's behavior (Miske, Dowd, et al., 1998), disciplinary policies (Craig, Kraft \& du Plessis, 1998) and free from violence (World Health Organization, 1998). Quality contents highlight the taught and intended curriculum of the institution (UNICEF, 2000). It includes non-discriminatory, student oriented and market-based curriculum structure (Glatthorn \& Jailall, 2000), literacy and numeracy (Furniss \& Green, 1993 and Steen, 1999). Quality process consists of professional learning for teachers (Darling-Hammond, 1997), teacher's working environment and teacher's beliefs (Postlewaithe, 1998), teacher's feedback mechanism, administrative support mechanism, using technologies (Denny, 2000). Quality outcome deals with knowledge, skills and attitudes gained from the institutions are linked to the national goals and social needs and demands (Botvin \&Willis, 1985).

\section{INGREDIENTS OF QUALITY EDUCATION AT TERTIARY LEVEL}

A. Institutional Vision and Mission: Institutional vision and mission are the prime policy of adopting quality education and a pathway to making country's future human asset. It is very essential to set a time worthy vision and mission strategy which will direct you to where you want to go. Clear and explicit vision and mission statement is required for every university that indicates the future destiny of the university. Quality vision and mission will address some important questions; what is the main aim of this university? Where the university wants to go tomorrow? How it becomes famous and prominent? Does it for research or course work? What kind of Human asset we are going to produce? What is the target or intentions of this institution? All above queries enumerates the essence of vision and mission of a university. It is observed that the organization that has more clear and measurable vision and mission statement gives double benefit compared to the organization which has no vision and mission strategy.

B. Curriculum and Syllabus: A quality curriculum and syllabus can ensure quality education. It helps you to plan for given period to process the education (Nunan, 1988). A lesson plan or a course plan is an example of curriculum. A lesson plan includes what will be given to the students? How it will be given? What will be the assessment system? What will be the instructional strategy? It will give you the complete glimpse of the lesson. If we talk about the course plan which indicates the course learning objectives and learning outcomes, contents that will be covered by the semester, the references from which the contents will be covered, date specific lesson plan. What to be taught? How to be taught? All the details are there in the course plan. A quality syllabus is made based on the demand of market and the demand of the society and state and aligned with the university vision and mission. So, syllabus includes the contents related to the course what is going to be taught (Kearsley and Lynch, 1996). It is considered as an instrument by means of which the teacher can achieve a degree of accomplishment between needs and social or individual actions in the class (Yalden, 1984). Think of a teacher is into the classroom without having a lesson plan, it is for sure that student will not learn anything apart from the fact that the teacher seems confused and the teacher would be mentally stressed out unnecessarily; a result of lack of planning (curriculum). Hence for a society to ensure quality education, it needs a curriculum and syllabus that is functional and relevant.

C. Faculties and Their Skills: Faculties are the most important stakeholder of state's education system. In modern time, faculties are supposed to create learning environment rather delivering the lecture in traditional way. Because students at the adult age are not always ready to hear but they 


\section{International Journal of Engineering Applied Sciences and Technology, 2020 \\ Vol. 4, Issue 11, ISSN No. 2455-2143, Pages 546-556 \\ Published Online March 2020 in IJEAST (http://www.ijeast.com)}

seek their interest on the delivered content (Pushkar, 2015). So, the prime responsibility of the faculty is to make them interested to the contents. It is really tough job but the quality and skilled teacher has the potentiality to motivate students. A teacher at tertiary level is not only a teacher but also a mentor, motivator and counselor to students. He works to develop innovation, critical thinking and problem solving skills of students (most important part of quality education) and preparing them for the market competition. With liberalization and globalization of economic activities, the necessity to develop skilled human resources of a high caliber is imperative. Consequently, the demand for internationally acceptable standards in higher education is evident (Nagoba and Mantri, 2015). So, preparing students for achieving core competencies what we have talked about is important and the faculties are entrusted to do this task. It requires some qualities of a faculty like innovative, creative, and entrepreneurial in their approach.

D. Environment of Educational Institutions: A convenient, safe and secured environment is pre-requisite for ensuring quality education. While often overlooked by policymakers, research shows that the learning environment significantly and positively impacts students' educational and life outcomes (Allen et al, 2011). Environment includes class rooms, departments, library, laboratory, residential hall where students normally move for their daily academic activities. The size of the class room according to student ration with all the modern aids is also the important part of this learning environment. Adequate library and laboratory facilities are determinants of quality education. Residential facility to the students is also significant to ensure quality in education. Educational research has consistently demonstrated that high quality learning environments, characterized by a positive school culture and climate are associated with academic achievement, effective risk prevention efforts and positive youth development (Parrett and Budge, 2012). In order for students to effectively learn, schools must create and provide a culture and climate that is hospitable to learning and engagement (Barth 2001). A positive learning environment includes;

- A quality learning environment is accessible and inclusive for all.

- A quality learning environment is safe and secure for all.

- A quality learning environment has adequate resources and infrastructure.

- Reasonable class sizes are essential to a quality learning environment.

E. Admission and Assessment of Students: Intake admission and their assessment system is also a major ingredient of quality higher education. The curriculum and syllabus of intake admission and their assessment system have a great influence on overall quality education of a country. Many students not prepared for tertiary education are getting admitted into universities. The high pass rate at HSC and SSC exams does not necessarily mean that the standards are improved correspondingly (Momin, 2016). It is impossible to construct a building without strong foundation, it would be unwise to expect an improvement of standards in higher education without improving the quality of primary, secondary and higher secondary institutes. Unfortunately the concept of university education is not clear to the most part of the population in Bangladesh. University is not really a place where the teachers have to "complete the syllabus" inside the classroom. Ideally by the time students reach the university, they are supposed to be matured enough to understand lectures and what is expected of them by their teachers (The Independent, August 4, 2016). So, the matured, knowledgeable and potential intake is the most important requirement for the quality education at tertiary level.

F. Teaching Instructional Strategies: Quality education refers student really understand something from the delivery of faculty. Research found that more than 100 teaching instructional strategies are available that a teacher can use in different time in different context for better understanding of students. Being an effective and quality teacher therefore requires the implementation of creative and innovative teaching strategies in order to meet students' individual needs. In this 21 st century, the traditional method of lecturing is not good enough for ensuring active learning in quality education. A faculty must understand the context and use the appropriate strategy so that student can really learn. On the other hand, a faculty with having different instructional strategies can tackle any kind of classroom setting to guide students towards success and putting a few of these techniques into practice will do wonders for his professional development. The most important instructional strategies are like Think pair-share (TPS), Jigsaw, Case Study, Presentation, Small Group Discussion, Academic Debate, Problem Solving, Lecturing, Close reading, SIOP strategies, Word wall and so on. Here constructive alignment is urgent for quality education. Keep in mind, which strategy a faculty follows during delivering content, the assessment system must be according to that strategy. For example, faculty followed case study method in the last class, he/she must prepare case study based question for assessment.

G. Workload of Faculties: Quality education is mostly depending on the faculty. Appropriate workload is also the big concern for quality. The university teachers are normally entrusted to doing three major tasks like teaching, research and service (Houston et al., 2006). Workload includes taking courses in a semester, taking classes, preparing lesson plan, evaluating the scripts, attending training programs and conferences, proctoring, coordinating different university activities, taking various administrative posts (other than academic) etc (Hosain, 2016). Amount of taking classes, 
preparing lesson plan, evaluating script will be more if you take more courses in a semester. I have seen, a teacher takes 4 or 5 courses ( 3 credit course) in a semester. How could it be possible to ensure quality? On the other hand, teacher has to do research and publication. Teacher's overload really hampers the quality of learning at tertiary level (Wakoli, 2016). So, an appropriate and logical workload is important for quality higher education.

H. Research: Without research none can ensure quality education especially at tertiary level. This modern era of globalization requires students with having quality of creativity, innovation, analytical, problem solving, for dealing with market competition. Research based education system puts all the mentioned qualities into the student at tertiary level. Faculty is entrusted to doing research and finding new solution to the social problem. Student's involvement in research work is necessary to make them in a way where they can conduct research to find a new solution of a problem. Connection of faculty and students to the research work is the prime requirement of ensuring quality education at tertiary level. Here, administrative and financial support for doing research is also important, without it, it will be tougher for the faculty, the student and the institution as well. Through detailed research, students develop critical thinking expertise, as well as effective analytical, research, and communication skills that are globally sought-after and incredibly beneficial. Ultimately, research is essential to economic and social development of our globalized society, forming the foundations governmental policies around the world (https://www.studyinternational.com/news/the-importance-ofresearch-and-its-impact-on-education). Research is one of the most important tools for ensuring that government policies and practices are thoughtful and effective.

I. Assessment and Feedback: Assessment of teaching and feedback from the students after semester may influence the quality of teaching at university level. It helps to improve the state of teaching learning by which nation will be benefited. Evaluation of Teacher Performance refers to the formal process a school uses to review and rate teachers' performance and effectiveness in the classroom. Ideally, the findings from these evaluations are used to provide feedback to teachers and guide their professional development (Sawchuk, 2015). Students may understand his faculties better about the classroom performance, so their feedback helps them (faculties) to enrich their knowledge and skills. In developed education system, this practice of teaching assessment and student feedback are encouraged massively. Evaluation can give one an insight on how teachers perform their roles as facilitator of learning inside the classroom which translates into students' learning achievement and their progress towards the desired skills and abilities (Bichi, 2017).
J. Ethics and Morality of Teaching: Ethics and morality of teaching is the prime concern of 21 st century education system with a view to ensuring quality higher education worldwide. Ethics and morality normally refers to identify gap between right and wrong, good and bad and pain and pleasure (Mahony, 2009). It's the basic concern that as a faculty am I doing right thing? As a student, am I doing right thing? Same question for other stakeholders of education system of a country will represent the moral and ethical standard of education. In general sense, ethics and morality of teaching includes; taking classes on time, being equal to everyone, applying equity if necessary, avoid horn effect and hello effect, avoiding biasness, loyal to the students and institution, owning the profession, taking preparation before entering into the class, being friendly not friend to the students etc. Teachers with a high level of moral professionalism have a deep obligation to help students learn and behave ethically which supports the students to have a sustained growth in their life. The major benefits of ethical students are they will be highly committed, taking responsibility, giving respect, high tolerance, non-discrimination, compassion, better understanding and good citizen (Shobana and Kanakarathinam, 2017).

\section{PRESENT STATE OF HIGHER EDUCATION IN BANGLADESH}

There are five types of higher education available in the country. These are: i. General Education ii. Science and Technology and Engineering Education iii. Medical Education; iv. Agricultural Education; v. Distance Education. In addition, the higher education sector also provides Vocational and Madrasah education (Monem and Baniamin, 2010). In Bangladesh, higher education consists of a 3 year pass-course or a 4 year Honours course for the bachelor's degree, followed by a two year Master's course for pass graduates and a one-year Master's course for Honours graduates (Monem and Baniamin, 2010). Universities in Bangladesh are mainly categorized into Public, Private and International universities. There are 154 universities in Bangladesh now. Among them, public universities are 46, private universities are 106 and international universities are 3 (UGC, 2019-2020, http://www.ugc.gov.bd). University Grants Commission (UGC) as the apex body of the government for higher education is responsible for funding of public universities. Though Private universities do not get any government assistance in terms of funding, they need to receive approval from the UGC to operate and award degrees. The number of students enrolled in universities has shot up from 4,11,717 in 2008 to10,28,314 in 2018 (BANBEIS) (The daily star, July 03, 2019). 


\section{International Journal of Engineering Applied Sciences and Technology, 2020 Vol. 4, Issue 11, ISSN No. 2455-2143, Pages 546-556 \\ Published Online March 2020 in IJEAST (http://www.ijeast.com)}

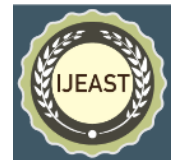

\section{THE HINDRANCES OF QUALITY HIGHER EDUCATION IN BANGLADESH}

University education of Bangladesh is hampered because of some serious hindrances. It is now a major allegation that the quality of higher education is declining rapidly, and in some areas quite alarmingly. According to academicians, researchers, various committees (University Grants Commission- led High Powered Committee, 2003) or commissions report (UGC, PSC), newspaper report and public perception, it seems that the university education is losing standard day by day (Akter, 2017). Followings are the hindrances of quality higher education in Bangladesh.

A. Unhealthy Student Politics: Unhealthy Student politics in educational institution is alarming for any country. A fresher admit into university for the sake of getting knowledge, learning about the world, knowing about the globe and making himself a qualified and fit graduate for the competitive market. They are supposed to do something for the well-being of the society and state. But unfortunately every university of Bangladesh has the high level practice of narrow politics. Students come to university and getting involved into politics. Sometimes they are pressurized to do it; we have seen it by newspapers. Student organizations of political parties are very active during their regime and try to engage more students into their politics. This unhealthy political practice deteriorates the warm environment of educational institution. The consequences of such student politics are very dangerous, recently we have seen it in BUET, many times in DU, RU, JU and CU; the top most university of Bangladesh. From 1972 to 2014, 147 students have been murdered, and every murder was related to politics. Some of the murders and tortures have not been reported in the media, but have been swept under the rug using political influence (Akil, Dhaka Tribune, and October 18th, 2019). Innocent students with no involvement in politics have been killed too. The situation indicates missing of student's safety and security inside university campus and residential hall in Bangladesh.

B. Politics in Faculty Recruitment: Faculty recruitment system in Bangladeshi universities is not similar to the other developed country. Most depressing fact is negative influence of politics in recruitment system. Teachers are the maker of nation, that's why qualified and skilled faculty member is required for ensuring quality education. We come to know by print and electronic media about faculty recruitment business which is becoming severe in Bangladesh. In most of the cases, Qualified and top class candidates are being ignored and less qualified are getting chance to be teacher of university because of severe corruption. A simple equation is, if teachers are not qualified, how can we expect quality teaching from them? Corruption is rampant in the recruitment process of lecturers in the country's public universities. Lecturers are paying an obscene amount of money to get recruited in public universities. The bribes range from $\mathrm{Tk} 3$ lakh to $\mathrm{Tk} 20$ lakh (Durjoy, TIB Report, and December 18th, 2016). TIB report also revealed allegations of unauthorized financial transactions in eight public universities and political patronage, nepotism, regionalism and religious identity as dominant drivers of corruption in the recruitment process at 13 public universities in Bangladesh (Karim, The Daily Star, and December 26, 2016).

C. Ineffective Faculty Development Programme: Quality and efficiency of education depends on teachers' ability to inculcating knowledge. Different programs are there generally called 'faculty development program' to give a glimpse of teaching to the newly recruited faculties so that they can provide quality teaching in the classroom. No recruitment system is perfect, to fill the gap, such program or training is needed to develop quality and skill and pedagogical knowledge of the faculty in the academia (Raqib, 2019). Unfortunately in Bangladesh, this program is ineffective. We see, teachers are recruited, joined to the department, without any training they enter into the classroom. Newly appointed faculties are unknown to the environment, they need some orientations; how to take class? How to handle the class settings? How to handle the students? How much teaching instructions are there and which one is suitable for which context?

D. Teacher's Involvement in Politics: Teachers are the idle to the students and they are supposed to be academician, researcher, and consultant not to be politician. It's a natural scenario in Bangladesh that teachers of university are engaged in politics; whether into the government party or the opposition. They engage themselves into politics for petty interests; mostly to get promotions and important positions in various organizations which give them power and financial benefits (Tithi, 2017). When teachers are appointed upon political consideration and engage in politics for personal interests, can we expect anything better from them? Because of political involvement of the teachers, public universities of Bangladesh are facing some problems like Question paper leaks of university entry exams have become a regular phenomenon, session jam is eating away precious time of students' academic life, quality of higher education is deteriorating due to lack of research activities, violent student politics is ruining the educational environment of the campuses, and so on (The daily Star, November 13, 2017).

E. Lack of Infrastructural Facilities: In Bangladesh, according to UGC website (2019-2020), we have 154 universities. Most of the universities are facing infrastructural problems like shortage of class rooms, faculty rooms, seminar rooms, insufficient library facilities, laboratory facilities and the most intensive one is student residential problems. Private universities do not have residential facilities. Also Public universities are facing sufficient dormitory problems. Only 


\section{International Journal of Engineering Applied Sciences and Technology, 2020 \\ Vol. 4, Issue 11, ISSN No. 2455-2143, Pages 546-556 \\ Published Online March 2020 in IJEAST (http://www.ijeast.com)}

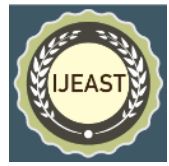

residential university of Bangladesh, Jahangirnagar University is not giving accommodation to the newcomers of 2020-2021 academic sessions. Library and laboratory conditions are not conducive for quality education. There is no denying the fact that the use of library facilities by students and teachers have declined over the years. The teachers in most cases seem to rely on particular texts and the students seems to possess increasingly poorer language ability to comprehend and explore the vast expanse of scholarship that the libraries hold. The libraries are poor as they lack adequate resources to buy recent publications and order for the basic journals. Likewise, the laboratories suffer from inadequacy of equipment. Most of the universities of Bangladesh do not have the practice of using modern teaching aids (laptop, projectors, digital white boards, electronic note-books, picture dictionaries, online dictionaries etc.) rather practicing traditional way of teaching.

F. Problem of Research: Bangladesh higher education is in a poor state regarding doing quality research. The faculties of universities have a big duty to do research but most of them are far from doing such quality research. There are some factors responsible for this situation; lack of funding, corruption, political handling of budget, and the intention of teacher also. In Bangladesh, we don't have specialized Research University rather having only teaching university. The faculties are intend to teach the students and do some research with minor funding just for increasing publication which is the ultimate requirements for promotion. Though, Universities set high qualifications including a requirement to publish a good number of research papers in world-class journals, which cannot be achieved by a marginally qualified group of teachers. Many of the 154 universities are not actively involved in basic and innovative applied researches (Hassan, 2019).

G. Curriculum and Syllabus: The curriculum and syllabus of higher education in Bangladesh is not need-based, market oriented, and related to international standard. As the university curriculum in Bangladesh is information-heavy, presenting facts to consume, and other analytic and operational tasks to practice and master, instruction and learning remain largely rote. The curriculum is designed without employer engagement and embedding programme objectives, programme outcomes and course learning outcomes. This curriculum does not facilitate the production of a skilled workforce, and it also does not give any directives to a course instructor in assessing student learning. The instructor sets questions just to measure what the students know about the subjects. Grade to a student for a course is assigned by the course instructor after aggregating the marks obtained in summative assessment, i.e. class tests and written examinations (The daily star, December 11, 2019). Using different types of teaching methods, taking formative assessment, preparing lesson outline with lesson objectives and outcomes, preparing course outline with course objectives and outcome are completely missing in most of the public universities. In most of the public universities has the duration of a class is $45-50$ minutes only that is really a problem to deliver a full lecture and taking feedback. Student feedback and evaluation of teachers is also absent in public universities which is essential for giving a room to the teachers for improving their performance and ensuring their accountabilities.

\section{PROPOSED FRAMEWORK FOR QUALITY HIGHER EDUCATION IN BANGLADESH}

The higher education in Bangladesh is suffering from some serious problems like problems of curriculum and syllabus, political involvement, lack of modern teaching aids, corruption in recruitment of faculty members, infrastructural limitations that are needed to be solved. It's true that tertiary level education does have some inbuilt and inherent problems; it can be corrected by overhauling the system. On that note, a proposed framework has been given bellow to be followed in higher education in Bangladesh. We hope it will help the authority to ensure quality higher education.

Figure-1: Elements of Quality Education

\begin{tabular}{|c|c|c|c|}
\hline \multicolumn{2}{|c|}{$\begin{array}{l}\frac{\text { Students }}{\text { 1. Intake Admission }} \\
\text { 2. Interest and motivation } \\
\text { 3. Counseling and } \\
\text { mentoring } \\
\text { 4. Recognizing student's } \\
\text { performance } \\
\text { 5. Scholarship and Stipends } \\
\text { 6. Student's Attendance } \\
\text { 7. Co-curricular activities }\end{array}$} & \multicolumn{2}{|c|}{$\begin{array}{l}\frac{\text { Faculties }}{\text { 1. Faculty Recruitment }} \\
\text { 2. Knowledge and Skills } \\
\text { 3. Loyalty and accountability } \\
\text { 4. Punctuality } \\
\text { 5. Salary and other allowances } \\
\text { 6. Workload } \\
\text { 7. Working Environment } \\
\text { 8. Student- Faculty relation } \\
\text { 9. Faculty development training }\end{array}$} \\
\hline $\begin{array}{l}\text { Research } \\
\text { 1. Research } \\
\text { based } \\
\text { university } \\
\text { 2. Publication } \\
\text { in high impact } \\
\text { factor journal } \\
\text { and indexing } \\
\text { 3. Funding for } \\
\text { research } \\
\text { 4. Research } \\
\text { based } \\
\text { curriculum } \\
\text { 5. Faculty } \\
\text { connection } \\
\text { with research } \\
\text { work }\end{array}$ & $\begin{array}{l}\text { Curric } \\
\text { Syllabu } \\
\text { 1. Univ } \\
\text { vision n } \\
\text { progran } \\
\text { objectiv } \\
\text { course 1 } \\
\text { objectiv } \\
\text { aligned } \\
\text { 2. Outc } \\
\text { oriented } \\
\text { 3. Mark } \\
\text { industry } \\
\text { 4. Need } \\
\text { 5. Follo } \\
\text { internat } \\
\text { Standar }\end{array}$ & 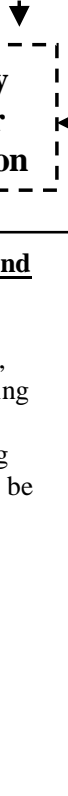 & $\begin{array}{l}\text { Resource } \\
\text { 1. Administrative } \\
\text { (Sufficient support } \\
\text { staffs, employees and } \\
\text { others) } \\
\text { 2. Academic } \\
\text { (Sufficient faculty } \\
\text { members, books and } \\
\text { journals, } \\
\text { 3. Financial } \\
\text { (Sufficient Budget and } \\
\text { effective and efficient } \\
\text { allocation of Budget) } \\
\text { 4. Infrastructural } \\
\text { (Classroom facilities, } \\
\text { library facilities, } \\
\text { laboratory facilities, and } \\
\text { residential facilities, } \\
\text { Modern teaching aids, } \\
\text { safe and secured } \\
\text { environment) }\end{array}$ \\
\hline
\end{tabular}




\section{International Journal of Engineering Applied Sciences and Technology, 2020 \\ Vol. 4, Issue 11, ISSN No. 2455-2143, Pages 546-556 \\ Published Online March 2020 in IJEAST (http://www.ijeast.com)}

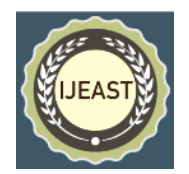

Above diagram indicates five key elements of quality higher education are Students, Faculties, Research, Resources, and Curriculum and Syllabus. The authority needs to take measures regarding this five mentioned areas collectively. The suggestions will be regarding these five areas;

A. Student: Intake admission should be in that way by which meritorious and genius students can get the opportunity to admit. Unhealthy student politics should be stopped from educational institution. A convenient and safe environment for the students must be ensured in the residential hall, department and campus area as well. Students have different problems like academic, personal or familial that create pressure upon them and make them out of the class room, for this reason, they may need mentoring and counseling, they need motivation and interest. A professional mentor/counselor is to be appointed for well-being of the students.

B. Faculty: Faculty recruitment system needs to be transparent and free from political influence, nepotism and corruption. Qualified and skilled candidates should be appointed. In this context, priority should be given to the merit, academic result and research work. A well-organized training program should be promoted for fresher faculty members to be oriented with pedagogical knowledge, skills and method before entering into the classroom. Faculty members shouldn't do politics but doing his entrusted task; teaching, research and service. They should be accountable, loyal and dedicated to teaching. A convenient workload is to be provided to the faculties not much than that. Faculty performance evaluation system is urgent to introduce so that quality of teaching will be improved. Faculties should be given all administrative and financial supports.

C. Research: Higher education in Bangladesh must be based on research; both faculty members and students must be participated in research activities. Funding for the research activities should be increased so that quality research will be conducted. It's necessary to make a provision for promotion that requires publications from high impact factor journal will ensure quality research. Research must be prioritized while designing curriculum of a program. Thesis, projects and dissertations should be encouraged and done accurately.

D. Resource: Here resources mean infrastructure and others. Sufficient faculty members, administrative staffs and their accommodation need to be ensured. Available classroom facilities, library facilities and laboratory facilities, accommodation of students should also be ensured. Modern teaching aids and its application should be encouraged in the classroom. Proper utilization of annual budget is important not it be politically handled.

E. Curriculum and Syllabus: Curriculum and syllabus should be time based, need based and market based for being able to compete in the market. A curriculum must be developed sequentially, beginning with aligning programme educational objectives with the institutional statement of vision and ending with the assessment of each student before and after graduation. Academic programmes must have definite and measurable programme educational objectives (PEOs) and programme outcomes (POs) for their students and programme offering departments must have tools to evaluate their efforts to achieve those objectives and amend their programmes based on the results of the assessment. Therefore, universities will not only emphasize on content knowledge acquiring but also on high-level skill development to produce the most employable graduates.

\section{CONCLUSION}

Higher education is the fundamental area of a country's sociopolitical and economic development. As creators and purveyors of knowledge, the universities' contributions are widely accepted. Quality higher education of a country depends on some important factors like vision and mission of institution, curriculum and syllabus, Knowledge and skills of faculty members, safe and secured campus environment, intake admission and student assessment, application of pedagogical instructions, appropriate workload, research and ethics and morality of teaching. Higher education in Bangladesh is in a state of flux while responding to the challenges of globalization in a local way because of having some limitation like politics of faculty recruitment system, unhealthy teacher and student's politics, ineffective faculty development program, huge gap in infrastructural facilities, lack of quality research, imbalanced curriculum and syllabus etc. Bangladesh government has taken initiatives to ensure quality higher education such as HEQEP project, IQAC cell in every university. This paper proposed a framework with five key elements; Student, Faculty, research, resources and curriculum and syllabus that will help authority and policy maker to take necessary measures for ensuring quality education. We need to focus on these five most important sectors of higher education.

'An ideal state depends on quality human resources, producing quality human resource is impossible without quality education'- Author

\section{REFERENCES}

[1]. Adams, D. (1993), 'Defining educational quality', Improving Educational Quality Project Publication \# 1: Biennial Report. Arlington, VA: Institute for International Research.

[2]. Akil, N., Z. (2019), 'The consequences of student politics', retrieved from Dhaka Tribune, October 18th, 2019 


\section{International Journal of Engineering Applied Sciences and Technology, 2020 \\ Vol. 4, Issue 11, ISSN No. 2455-2143, Pages 546-556 \\ Published Online March 2020 in IJEAST (http://www.ijeast.com)}

adapted from https://www.dhakatribune.com/opinion/oped/2019/10/18/the-consequences-of-student-politics.

[3]. Akter, A. (2017), 'Factors to Improve the Quality of Higher Education in the Non-Government Universities in Bangladesh', International Journal of Education, Culture and Society, Vol. 2(4), (Pp.132-142).

[4]. Allen, D. E., Donham, R. S., and Bernhardt, S. A., (2011), 'Problem-based learning', Wiley Online Library, Adapted from https://onlinelibrary.wiley.com/doi/epdf/10.1002/tl.465, https://doi.org/10.1002/tl.465

[5]. Aminuzzaman, S., M. (2011), 'Quality issues of higher education in Bangladesh', Journal of General Education, Vol.1, (Pp. 1-15).

[6]. Andaleeb, S. S., (2003), 'Revitalizing higher education in Bangladesh: Insights from alumni and policy prescriptions', Higher Education Policy, 16 (4), (pp. 487-504).

[7]. Andaleeb, S. S., (2019), 'Teaching load: The missing link in higher education quality', the daily star retrieved from, June 13, 2019.

[8]. Barth, R. S., (2001), 'Teacher Leader', The Journal of PDK international (SAGE), Vol. 82(6): (Pp. 443-449).

[9]. Bernard, A. (1999), 'The child-friendly school: a summary', Paper written for UNICEF, New York.

[10]. Bichi, A. A., (2017), 'Evaluation of Teacher Performance in Schools: Implication for Sustainable Development Goals', Northwest Journal of Educational Studies, Vol. 2(1), (Pp.103-113).

[11]. Botvin, G. and Willis, T. A., (1985). Social and Personal Skills Training: Cognitive behavioral approaches to substance abuse prevention. In CS Bell \& R., Battjes (Eds.) 'Prevention Research: Deterring Drug Abuse Among Children and Adolescents', (DHHS Publication No. (ADM) 87-1334). Washington D.C.: U.S. Government Printing Office.

[12]. Craig, H., Kraft, R. and du Plessis, J. (1998). Teacher development: Making an impact. Washington, D.C.: Academy for Educational Development, ABEL Clearinghouse for Basic Education.

[13]. Darling-Hammond, L., (1997), 'Doing what matters most: Investing in quality teaching', Kurtztown, Pennsylvania: National Commission on Teaching and America's Future. Also at http://www.tc.columbia.edu/ teachcomm.

[14]. Denny, C. (2000, Feb. 1). Internet promises salvation - or an even bigger knowledge gap. The Guardian.
[15]. Durjoy, N., A. (2016), 'TIB: Corruption rampant in public university teacher recruitment', retrieved from Dhaka Tribune, December 18th, 2016, adapted from https://www.dhakatribune.com/bangladesh/corruption/2016/12 118/money-trumps-credentials-public-uni-teacher-recruitment.

[16]. Glatthorn, A. and Jailall, J., (2000), 'Curriculum for the new millennium. In Brandt', R. (ed.), Education in a new era: ASCD Yearbook 2000. Alexandria, Virginia: Association for Supervision and Curriculum Development.

[17]. Hassan, M., M., S. (2017), 'Quality in Higher Education: Bangladesh Perspective', retrieved from The daily sun, 16 July, 2017.

[18]. Hassan, M., M., S. (2019), 'Research universities can light the way for tomorrow's Bangladesh', retrieved from The daily star, 3 July, 2019.

[19]. Hosain, M., S. (2016), 'Teaching Workload and Performance: An Empirical Analysis on Some Selected Private Universities of Bangladesh', International Journal of English and Education, Vol. 5(3), (Pp. 1-11).

[20]. Hossain, M., B. (2017), 'Factors Affecting Higher Education Quality in Bangladesh: An Attempt to Improve Higher Education Quality in Bangladesh through HEQEP', International Journal of Science and Business, Vol: 1(1), (Pp.; 47-59).

[21]. Houston, D., Luana, H., M., \& Shelley, P. (2006), 'Academic Staff Workloads and Job Satisfaction: Expectations and Values in academe', Journal of Higher Education Policy and Management, Vol. 28(1), (Pp. 17-30).

[22]. Islam, S., and Himel, S., H. (2018), 'Services Quality and Students' Satisfaction: A Study on the Public Higher Education Institutions (HEIs) of Bangladesh', Journal of Business Studies, (Pp. 21-27).

[23]. Karim, M., R. (2016), 'How to stop corruption in recruitment of university teachers', retrieved from The Daily Star, December 26, 2016, adapted from https://www.thedailystar.net/opinion/society/how-stopcorruption-recruitment-university-teachers-1335397.

[24]. Kearsley, G. and Lynch, W. (1996), 'Structural issues in distance education', Journal of Education for Business, Vol. 71(4), (pp. 191-196).

[25]. Mahony, P., (2009), 'Should 'ought' be taught?', Teaching and Teacher Education, Vol. 25(7), (Pp. 983-989). 


\section{International Journal of Engineering Applied Sciences and Technology, 2020 Vol. 4, Issue 11, ISSN No. 2455-2143, Pages 546-556 \\ Published Online March 2020 in IJEAST (http://www.ijeast.com)}

[26]. McCain, M. and Mustard, J. F. (1999). Reversing the real brain drain: Early years study. Toronto, Canada: Publications Ontario.

[27]. Miske, S., Dowd, A. (1998), 'Teaching and learning in Mangochi classrooms: Combining quantitative and qualitative information to study twelve primary schools in Malawi', Evaluation study conducted for the United States Agency for International Development by Creative Associates International, Washington, D.C.

[28]. Momin, S., M. (2016), 'Ensuring quality in higher education', retrieved from the independent, August 4, 2016.

[29]. Monem, M. and Baniamin, H. M. (2010), 'Higher Education in Bangladesh: Status, Issues and Prospects', Pakistan Journal of Social Sciences (PJSS), Vol. 30(2), (pp. 293-305).

[30]. Nagoba, S. B. and Mantri, B. S. (2015), 'Role of Teachers in Quality Enhancement in Higher Education', Journal of Krishna Institute of Medical Sciences University, Vol. 4(1), (Pp. 177-182).

[31]. Nunan, D. (1988). Syllabus Design. Oxford: Oxford University Press.

[32]. Parrett, W. H. and Budge, K. M. (2012). Turning HighPoverty Schools into High-Performing Schools. Alexandria: ASCD publications, USA.

[33]. Postlewaithe, N. (1998), 'The conditions of primary schools in least-developed countries', International Review of Education, Vol. 44(4), (Pp. 289-317).

[34]. Pushkar, M. P. (2015), 'Role of Teacher In Higher Education', International Journal of Education and Information Studies, ISSN 2277-3169, Vol. 5(1), (pp. 25-30).

[35]. Rahman, M. A. (2010), 'Commercialization of education in Bangladesh: Problems and solutions', NAEM Journal, Vol. 5(10), (Pp.1-11).

[36]. Rashid, M. M. and Rahman, M. Z. (2017), 'Quality of Higher Education in Bangladesh: Application of A Modified SERVQUAL Model', Problems of Education in the 21st Century, Vol. 75(1), (Pp. 72-91).

[37]. Raqib, A. (2019), 'Innovations in Teachers Training at Higher Education in Bangladesh', Social Science Review (The Dhaka University Studies, Part-D), Vol.36(1), (Pp. 221-231).

[38]. Sawchuk, S. (2015), 'Issues A-Z: Teacher evaluation: An issue overview', Education Week. Retrieved April, 24,
2017

from

http://www.edweek.org/ew/section/multimedia/teacherperformance-evaluation-issue-overview.html.

[39]. Shobana, S. and Kanakarathinam, R. (2017), 'Awareness and Need of Ethics and Values in Education for Students: A Study among College Teachers in Pollachi Region', IJCRR, Vol. 9(9), (Pp. 26-31).

[40]. Steen, L. (1999), 'Numeracy: The new literacy for a data-drenched society', Educational Leadership, Vol. 57(2), (Pp. 8-13).

[41]. Sutton, M., et al., (1999), 'Promoting primary education for girls in Guinea'. Impact evaluation number PN-ACA-915. Arlington, Virginia: United States Agency for International Development's Development Experience Clearinghouse.

[42]. The Daily star, December 11, 2019 adapted from https://www.thedailystar.net/opinion/education/news/assessme nt-university-courses-must-be-innovative-realistic-andrelevant-1838530.

[43]. The Independent, August 4, 2016 Adapted from http://www.theindependentbd.com/post/54276

[44]. Tithi, N. (2017), 'Teacher politics: Plaguing our public universities', Retrieved from the daily star, November 13, 2017, adapted from https://www.thedailystar.net/opinion/society/teacher-politicsplaguing-our-public-universities-1490188.

[45]. UNICEF, (2000), 'Curriculum report card', Working Paper Series, Education Section, Programme Division. New York, NY: Author.

[46]. U.S. Department of Education, (2006), 'Accreditation in the United States, National Recognition of Accrediting Agencies by the U.S. Secretary of Education'. Washington, DC: U.S. Department of Education.

[47]. Wakoli, C. (2016), 'Effects of Workload on the Teachers' Performance in Kanduyi Division, Bungoma District', International Journal of Science and Research (IJSR), Vol. 5(10), (Pp. 1215-1219).

[48]. World Health Organization, (1998), Violence prevention: An important element of a health-promoting school. Geneva: Author. Also available at http://www.who.ch/hpr.

[49]. Yalden, J. (1987). Principles of Course Design for Language Teaching. Cambridge: Cambridge University Press. 


\title{
ACKNOWLEDGEMENT
}

\begin{abstract}
All praises and complements belongs to almighty for helping me to accomplish this writing. I am indebted to my mother for her uncoditional support througout my journey. I always remember my father (Late) who had a dream of making his child a university teacher what I am today. I also owe special gratitude to my all teachers who taught me a lot in and outside of academia. Finally I want to take this privilege to express my heartfelt gratitude to the team of IJEAST for your kind cooperation and response.
\end{abstract}

